\title{
Research on the Fundamentals of Architectural Restoration Associate Degree Program
}

\author{
Ozlem Atalan ${ }^{1, *}$ \\ ${ }^{1}$ Manisa Celal Bayar University, Architectural Restoration Program, Kula Vocational School, Manisa, \\ Turkey
}

\begin{abstract}
Today, the effects of globalization can be easily seen in many areas in the world. In the changing process, both Architectural education and side branches need various updates. The "Architectural Restoration Program", which is one of these branches of Architectural education, aims to provide to the sector "Technicians" and educates "Architect Candidates". The "Architectural Restoration Associate Degree Program" is a two year degree. In this context, the importance of this program's course curriculums is great. The Program is aimed to train qualified technical personnel for cultural assets that are common heritage of mankind which must be transferred to future generations. Program's graduates work in the laboratories, on the construction site and office, in the archaeological excavation, as a technical staff with architects. In this study, the relationship between "Architectural Education" and the basic objectives of the "Architectural Restoration Program" is examined. In this study, various Turkish and American universities' "Architectural Restoration Program" module details will be subject for a further examination and evaluation
\end{abstract}

\section{Introduction}

In the field of architecture and urbanization, the effects of globalization are affecting our historic cities [3]. Different courses and information are needed in both architectural education and education of side branches. The "Architectural Restoration Program", guiding the future of the historic cities, is an important program in the field of architecture sciences. This program educates architect candidates as well as bringing in technical engineers with two years of education. In this context, the importance of the curriculum that will be included in this program is great.

In Turkey, Architectural Restoration Program is located in the Vocational School. "Architecture and Urban Planning Departments" also provides training as an associate degree program. At the end of the Architectural Restoration program, students graduate with the title of "technician". In general, the aim of the Architectural Restoration Program is to educate qualified technical personnel for cultural assets that are a common heritage of mankind and must be passed on to future generations. Our aim is that after graduating from

*Corresponding author: oatalan@hotmail.com; ozlem.atalan@cbu.edu.tr 
this program students will be able to work in the laboratories, on the construction sites, in the archaeological excavation teams, as a technical staff. Over the two years of training, the student will learn a large number of different field lessons.

Scope of research;

- Four situations (Associate Degree Programs Architectural Restoration) were examined in the Turkey and Worldwide.

- Basics of Architectural Undergraduate Education and Architectural Restoration Associate Education have been researched.

- Objectives to be achieved in the training of Architectural Restoration Programs are discussed.

\section{Fundamental Points of Architectural Restoration Program}

Architectural restoration programs offer academic curriculum that ranges from restoration methods and conservation theory to courses designed to allow students to learn various trades used in preserving historical heritage. Techniques learned in the class and the field labs are then practiced on real preservation projects.

These programs are aimed to teach students the basic professional acquisitions that are used to preserve and restore historic heritages. Architectural Restoration Program's outcomes are to have a thorough understanding of historic preservation theory and be able to apply that theory in real life situations. Moreover, at the end of the program students will be able to understand the materials and the basic concepts behind the techniques used in the conservation of historic buildings and will be able to carry out those methods when necessary. Graduates of this program will be capable to work successfully in the business environment, develop an effective work ethic and make quality workmanship.

The title of Architectural Restoration Technician requires some technical skills. Graduated students can draw in both modern and traditional architecture. Graduated students can take part in the restoration and restitution projects and applications. They will be able to support the architect and engineer in need. In other words, they will contribute to the field of architecture.

Architecture; Due to its close relationship with technology, engineering, science and art, and because it has many disciplines, it needs a common language. In architecture this language is drawings. It is necessary to know this language both in the field of architecture and in the Architectural Restoration Associate Degree Program. The most important courses that develop the language of drawing in Architecture, Interior Architecture, Planning and Design fields are the courses called "Technical Drawing, Perspective, Space Geometry and Design Geometry. The architectural restoration associate degree program consists of four semesters.

Two-year architectural restoration programs are similar in terms of course content and programs. However, in some universities, the "workplace practice internship", which has become widespread in recent years, has entered the curriculum. There are about six fields in the program.

(1) Construction Courses (Theoretical and Practical): Traditional Construction Technique, Structure, Building Material and Details, etc.

(2) Drawing Courses (Theoretical and Practical): Technical Drawing and Computer Aided Design, etc.

(3) Conservation and Restoration (Theoretical): Historical Sites, Cultural Heritages, Restoration and Conservation, etc.

(4) History Courses (Theoretical): Art, Architecture and Civilization History, etc.

(5) Conservation and Restoration (Theoretical and Practical) Courses: Building Conservation Technique, etc. 
(6) Others Courses: Mathematics, Chemistry, Language, etc.

\subsection{Construction courses (theoretical and practical): Traditional construction technique, structure, building material and details, etc.}

Explanation of building techniques in Turkish Architecture has been made by examining and drawing civil and monumental constructions. Monumental and civil structures inform about historical and traditional construction systems and building elements. These structures are demonstrated to the students. Traditional wood, carcass and masonry construction systems, materials and structural systems are taught. Additionally, drawing of plans, sections, facades and details of these constructions is taught. Introductions of building materials and application information are taught to the students. Doors, windows, etc and their decorative details are introduced to the students. These building elements are taught drawing.

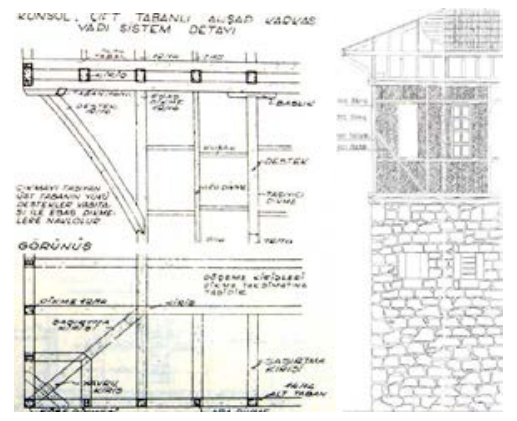

Fig. 1. Traditional Turkish House drawings, details and section $[4,5]$

\subsection{Drawing courses (theoretical and practical): Technical drawing and computer aided design, etc.}

The technical drawing is a language using special lines and symbols. It provides a common language and a communication between architects, engineers and other technical staff.

In this respect, it is necessary that every technical person who will take part in the production has learned the technical drawing rules and methods. Nonetheless, technical drawings, facilitates mutual understanding and ensures regular production [2]. In these lectures, drawing tools, basic drawing techniques and architectural project drawings are taught theoretically and practically. Having said that, the program seeks to introduce the leading computer aided drawing programs and to teach computer usage during the architectural and restoration drawing.

\subsection{Conservation and restoration (theoretical): Historical sites, cultural heritages, restoration and conservation, etc.}

The importance of environmental protection in the word, its definition, development process and legislation of conservation are taught in these courses. By introducing rural heritage, traditional heritage and archaeological heritage, contemporary problems are evaluated. Cultural assets in national and international scale, factors causing deterioration in monuments, types of deterioration are taught. During the restoration work, before and after the completion of the work phases, the principles of intervention for protection are exemplified. 
Measurement techniques are taught theoretically and practically in the courses. Students, separated into groups, are asked to measure the historical monuments or the heritages. Drawings were made in scale. That said, students are taught restitution and restoration projects and preparation techniques.
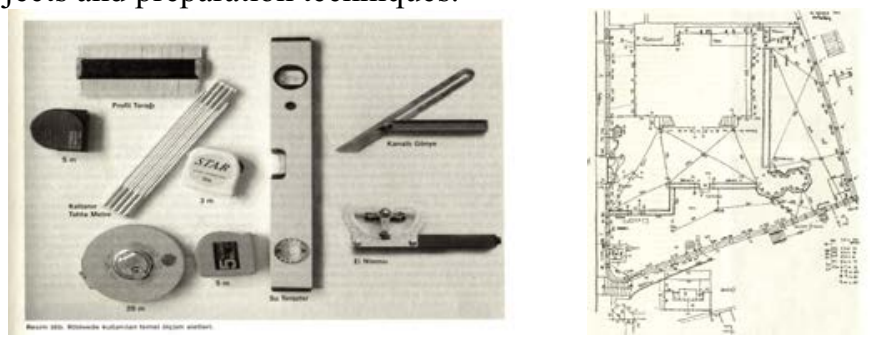

Fig. 2. Basic Measuring Tools [1]

Fig. 3. Measurement Drawings [1].

\subsection{History courses (theoretical): Art, architecture and civilization history, etc.}

In these lectures, the developments of styles, architecture and urban planning related to Islam and later are explained from prehistoric times. European and Western civilization, architectural and urban planning progress is explained.

Monumental and civil architectural heritages; architectural plan and facades schemes, usage typology, material, construction technique are examined. Archaeological heritages, Ottoman architecture, European, World architecture, their development processes and features are explained.

\subsection{Conservation and restoration (theoretical and practical): Building conservation technique, etc.}

In these lessons, firstly the traditional production techniques are explained. Conservation methods, terracotta works, glass and metal works are taught. The principles and methods to be followed in conservation and restoration of cultural assets are informed. The program includes theoretical and practical courses such as "stone and metal technology", "mosaic construction techniques", architectural ornament and repair", "stone and facade cleaning", "conservation and restoration methods".

\subsection{Others Courses}

All courses in this area improve the professional competences of students and at the same time courses contribute to the general cultural knowledge of the student. All samples were evaluated using AKTS rate.

\section{Architectural restoration programs examples in Turkey}

\subsection{Example 1: Yildiz Technical University, National Palaces and Historical Buildings Vocational School, Architectural Restoration Program, Istanbul, Turkey}

The purpose of the Architectural Restoration Program is to provide vocational education on national and international criteria in Yildiz Technical University. The program trains 
technicians to work in architectural protection and renovation works of palace, pavilion and historical monuments [9]. The lecture list of this program is given below.

Courses (AKTS):

1.st Semester: Ornamentation on Traditional Buildings (3), Materials of Traditional Buildings (3), Theory of Conservation (5), Technical Drawing, (5), History of Art and Civilization (4), Computer 1 (3)

2.nd Semester: Elective 1 (4), Elective 2 (4), Internship 1 (3), Computer (3), Documentation with Photography (2), Degradation Reasons and Conservation Methods on Traditional Buildings (2), History of Architecture 1 (2), Survey (4)

3. rd Semester: Elective 3 (3), Elective 4 (3), Elective 5 (4), Conservation 1 (3), Restoration Chemistry 1 (3), Metal Material on Traditional Building (2) , Research, Measuring and Documentation (2), History of Architecture 2 (2), Restoration Project 1 (8)

4. th Semester: Elective 6 (4), Elective 7 (4), Elective 8 (4), Internship 2 (3), Restoration Project 1 (9), Conservation 2 (3), Restoration Chemistry 2 (3)

Elective Courses 1 (4): Traditional Buildings and Interior Analysis, Traditional Buildings and Facade Analysis.

Elective Courses 2 (4 AKTS): Traditional Pattern Techniques, Materials of Traditional Buildings 2.

Elective Courses 3 (4 AKTS): Timber and Building Technology (4), Masonry and Building Technology, Wall, Floor and Ceiling Design of Traditional Building, Doors and Windows on Traditional Buildings.

Elective Courses 4 (4 AKTS):Degradation Reasons and Conservation Methods on Wooden Buildings, Degradation Reasons and Conservation Methods on Masonry Buildings, Degradation Reasons and Conservation Methods of Wall Surfaces.

Elective Courses 5 (4 AKTS): Wooden Ornamentation Techniques, Masonry Ornamentation Techniques, Degradation Reasons and Conservation Methods of Doors and Windows.

Elective Courses 6-7-8 (4 AKTS): Workshop of Timber, Workshop of Stone, Workshop of Furniture, Workshop of Metal, Workshop of Engraving, Workshop of Painting, Workshop of Textile [9].

\subsection{Example 2: Mimar Sinan Fine Art University, Architectural Restoration Program, Vocational School, Istanbul, Turkey}

Mimar Sinan Fine Art University, Vocational School educates technical staff to prepare the restoration, restitution and restoration projects of old buildings in the country. The Architectural Restoration Program, which was established to train qualified personnel who will take part in restoration workshops of the constructions, practice lessons as well as theoretical training [8].

Courses (AKTS):

1.st Semester: Cost Estimation (3), Technical Drawing 1 (4), Systems and Elements of Traditional Construction 1 (3), Measured Drawings 1 (4). Finishing Materials 1 (3), Technical Drawings 1 (4), Immovable Culture Monuments (3)

2.nd Semester: Systems and Elements of Traditional Construction 2 (3), Technical Drawing 1 (4), Internship (6), Finishing Materials 2 (3), Measured Drawings 2 (4)

3. rd Semester: Introduction To Restoration Techniques (3), Fine Arts I (3), Building Materials 1 (4), Computer Aided Design 1 (3), Techniques of Ornamentation and Restoration (3)

4. th Semester: Fine Arts 2 (3), Introduction To Restoration Projects (4), Building Materials 2 (3), Computer Aided Design 2 (3), Pattern Making in Turkish Ornaments (3). 
Elective Courses (AKTS): Use of Metal and Conservation Methods (3), Use of Photography in Measured Drawings (3), Mosaics: Construction Techniques, Courses Of Deterioration, Methods Of Preservation Of Restoration (3), Reading in Ottoman Language (3), Model, Practices of Natural Stone and Conservation Methods (3), Use of Photography in Measured Drawings (3), Glossary of Traditional Architecture (3), Late Period of Ottoman Architecture (3), Use of Wood and Conservation Methods (3), Late Period of Surface Painting Practices (3), Material Problems in Historical Buildings (3), Measured Drawings 3, Professional Practice (3), Use of Metal in Historical Buildings and Conservation Methods (3), Use of Photography in Measured Drawings (3), Mosaics: Construction Techniques (3), Courses Of Deterioration, Methods Of Preservation Of Restoration (3), Reading in Ottoman Language (3), Construction Details of Historical Buildings (3)

Table 1. Architectural restoration program's branches of courses (Example 1)

\begin{tabular}{|c|c|c|c|c|}
\hline \multicolumn{5}{|c|}{$\begin{array}{l}\text { Architectural Restoration Program's Branches of Courses } \\
\text { (Theoretical And Practical Education, AKTS) }\end{array}$} \\
\hline $\begin{array}{l}\text { Construction } \\
\text { Courses } \\
\text { (Theoretical } \\
\text { And } \\
\text { Practical } \\
\text { Education) }\end{array}$ & \begin{tabular}{|l} 
Technical \\
Graphic \\
Drawing and \\
Computer \\
Aided Design \\
Courses \\
(Theoretical \\
And \\
Practical \\
Education)
\end{tabular} & \begin{tabular}{|l} 
Historical Sites, \\
Cultural \\
Heritages, \\
Building \\
Conservation, \\
Restoration \\
Project, Survey, \\
Courses \\
(Theoretical And \\
Practical \\
Education)
\end{tabular} & \begin{tabular}{|l} 
History of \\
Architecture/A \\
rt /Civilization \\
(Theoretical)
\end{tabular} & 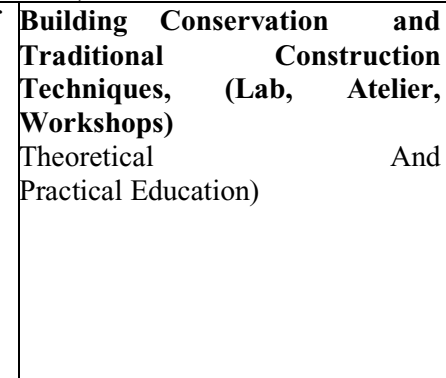 \\
\hline \begin{tabular}{|l} 
(1) \\
Materials of \\
Traditional \\
Buildings (3), \\
Materials \\
Details (3), \\
Traditional \\
Buildings and \\
Interior \\
Analysis (4), \\
Traditional \\
Buildings \\
and Facade \\
Analysis (4), \\
Materials of \\
Traditional \\
Buildings 2 \\
(4). Wall, \\
Floor and \\
Ceiling Design \\
of Traditional \\
Building (4), \\
Doors and \\
Windows on \\
Traditional \\
Buildings (4),
\end{tabular} & \begin{tabular}{|l|} 
(2) \\
Technical \\
Drawing, (5), \\
Computer 1 \\
(3) Computer \\
2 (3)
\end{tabular} & \begin{tabular}{|l} 
(3) \\
Theory of \\
Conservation(5), \\
Survey (4) \\
Documentation \\
with Photography \\
(2), Degradation \\
Reasons and \\
Conservation \\
Methods on \\
Traditional \\
Buildings (2), \\
Research, \\
Measuring and \\
Documentation \\
(2), Restoration \\
Project 1 (8),
\end{tabular} & $\begin{array}{l}\text { (4) } \\
\text { History of Art } \\
\text { and Civilization } \\
\text { (4) History of } \\
\text { Architecture } 1 \\
\text { (2), History of } \\
\text { Architecture } 2 \\
\text { (2) }\end{array}$ & 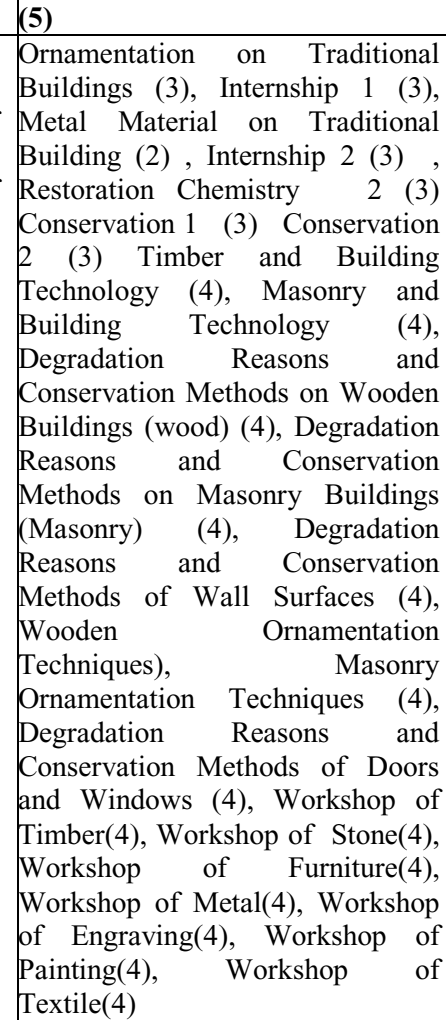 \\
\hline
\end{tabular}


Table 2. Architectural restoration program's courses (Example 2)

\begin{tabular}{|c|c|c|c|c|}
\hline \multicolumn{5}{|c|}{$\begin{array}{c}\text { Compulsory And Elective Courses } \\
\text { (Theoretical And Practical Education, AKTS) }\end{array}$} \\
\hline 1) $\downarrow$ & (2) $\downarrow$ & (3) $\downarrow$ & (4) $\downarrow$ & (5) $\downarrow$ \\
\hline 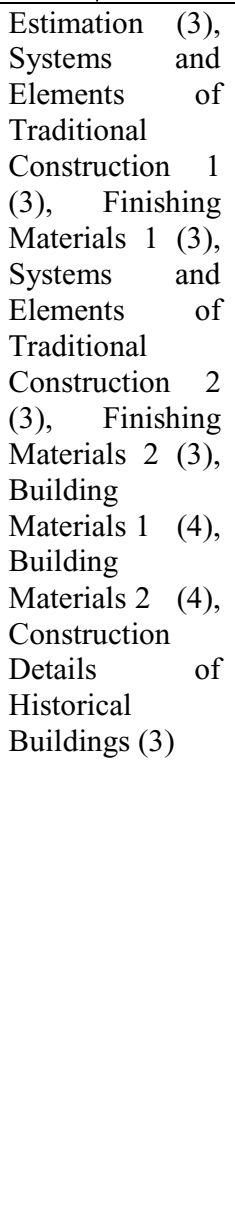 & $\begin{array}{l}\text { Technical } \\
\text { Drawing } 1 \\
\text { (4), } \\
\text { Technical } \\
\text { Drawings } 2 \\
\text { (4), } \\
\text { Computer } \\
\text { Aided } \\
\text { Design } \quad 1 \\
\text { (3), } \\
\text { Computer } \\
\text { Aided } \\
\text { Design } \quad 2 \\
\text { (3), }\end{array}$ & $\begin{array}{l}\text { Measured Drawings } 1 \\
\text { (4), Immovable Culture } \\
\text { Monuments (3) } \\
\text { Measured Drawings } 2 \\
\text { (4) Introduction To } \\
\text { Restoration Techniques } \\
\text { (3), Use of Photography } \\
\text { in Measured Drawings } \\
\text { (3), Mosaics: } \\
\text { Construction } \\
\text { Techniques, Courses Of } \\
\text { Deterioration, Methods } \\
\text { Of Preservation Of } \\
\text { Restoration (3), Glossary } \\
\text { of Traditional } \\
\text { Architecture (3), } \\
\text { Measured Drawings 3, }\end{array}$ & $\begin{array}{l}\text { Fine Arts } \\
\text { I (3), } \\
\text { Reading } \\
\text { in } \\
\text { Ottoman } \\
\text { Languag } \\
\text { e (3), } \\
\text { Late } \\
\text { Period of } \\
\text { Ottoman } \\
\text { Architect } \\
\text { ure (3 }\end{array}$ & 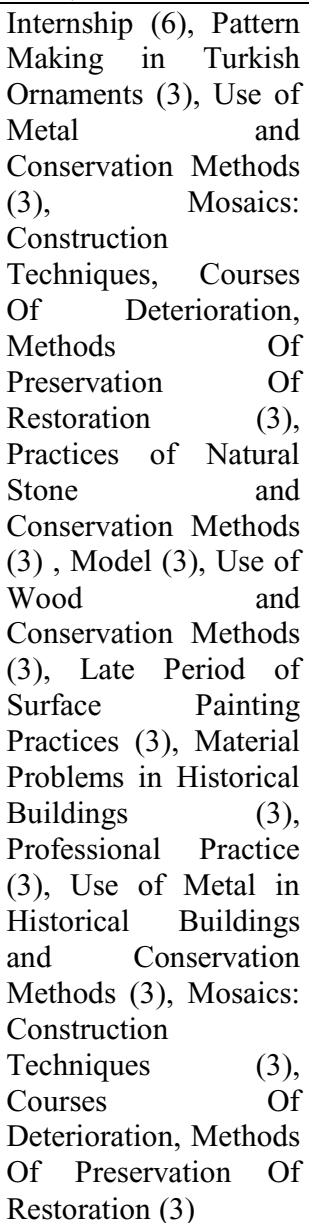 \\
\hline
\end{tabular}

\section{Architectural restoration programs examples in the World}

The Architectural Restoration Program is located in many universities and colleges around the world. It takes 2 years (4 semesters). Graduates may tend towards various branches such as "Architect, Blacksmith, Carpenter, Curator, Decorative Painter, Economic Development Specialist, Grant developer or Manager, Heritage Tourism Specialist, Historian, Historic Site Supervisor, Mason, Materials Conservator, Museum Administrator, National Park Service Specialist, Plasterer, Preservation Consultant, Preservation Contractor, Preservation Design Consultant, Restoration Artisan, Stained Glass Artisan, Compliance Specialist, State Historic Preservation Office Specialist" and continue their education.

Architectural Restoration Associate Degrees are located in universities and colleges in America. Below is "Belmont College" and "Clatsop Community College"s "The Building Preservation /Restoration Program". It appears that the programs consist of 4 semesters. 
These colleges provide an affordable way for students to transfer to a four-year college and a bachelor's degree. Many students complete the first two years of their bachelor's degree at these colleges and then transfer to a four-year-school to finish. A typical choice is to get an Associate of Arts or an Associate of Science degree [6,7].

\subsection{Example 3: Belmount College The Building Preservation/Restoration Program, Cadiz, OH, USA (Associate of Applied Science Degree)}

Education offers a foundation in preservation theory and history together with an indepth technical analysis of why buildings and materials fail and explores traditional and modern approaches used to repair cultural heritages. Students have the chance to apply their theoretical course knowledge in though workshops in order to learn the fundamentals of restoration technique. Students also practice the techniques learned in the workshops on real-world preservation projects. Students work on the department's own historic field lab house and completing community based projects [6].

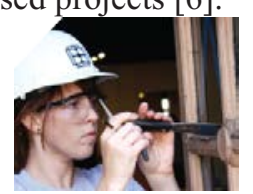

Picture 1. The Building Preservation/Restoration Program Education [6]

Courses (AKTS):

1.st Semester: Introduction to Historic Preservation (3 ), Architectural Drafting and Design (3), Materials and Methods of Construction (3 ), Composition 1, History of American Architecture 1

2.nd Semester: Historic Research and Documentation (2 ), History of American Architecture 2 (3), Restricted Elective(3), Material Science Elective(3), Math Elective(3)

Summer Term: Field Lab Community Service (1), Material Science Elective (3)

3. rd Semester: Building Pathology (4), Speech (3), Field Lab. (1), Material Science Elective (3), Social Science Elective (3)

4.th Semester: Construction Management and Estimating (3), Chemistry for Conservation(3), Field Lab. (1), Material Science Elective (3), Social Science Elective (3), Restricted Elective (3) Summer Term: Capstone (2)

Restricted Elective: Mechanical Systems (3), Windows and Doors (3), Roofing and Flooring (3), Specials Problems 1 (3), Directed Studies 1 (3)

Materials Science Electives: Decorative Finishes (3), Masonry and Ceramics (3), Plaster and Composition (3), Metals (3), Stained Glass (3)

\subsection{Example 4: Clatsop Community College, Astoria, Oregon, USA (Associate of Applied Science Degree)}

Students learn function and performance characteristics of historic building materials, methods and sequence. Both modern and historic materials are examined. Students study tools and techniques for sketching and drafting for architecture, and improve communication skills for construction and restoration projects. They improve skills to document historic heritages and survey measured drawings [7].

Courses (AKTS):

1.st Semester: Introduction to Historic Preservation (2), Construction Math (2), : Construction Safety for Historic Preservation (1), Printreading for Construction (3), 
Computer Aided Design 1 (4), Workshop: Wood Window Replication (2), Beginning Stone Masonry (1), Plaster Repair (2)

2.nd Semester: Project Management (3), Historic Preservation 1 (3), Computer Aided Design 1 (4), Printreading for Construction (3). Workshops: Facade Restoration (2) , Fundamentals of Woodworking (2), Faux Finish Techniques (1)

3.rd Semester: Residential Materials \& Method (3), s, Construction Drawing (3), Computer Aided Design 2 (3), Computer Graphics (3), Workshop: Wood Window Restoration, Decorative Glass Glue Chipping, Plaster Repair

4.nd Semester: History of Pacific Northwest (3), Computer Aided Design 3 (4), Computer Graphics 2 (4), Historic Preservation Project (4), Workshops: Dry Stack Masonry (3), Monument Restoration (2)

Selected Work Shop Courses: Blacksmithing, Building Documentation, Column Restoration, Dry Stack Masonry, Deck Reconstruction, Documentation \& Deconstruction, Door Analysis, Door Reconstruction, Facade Restoration, Faux Finish, Floor Framing, Historic Glass, Millwork, Ornamental Plaster, Plaster, Porch Restoration Roof Restoration, Stained Glass, Stair Layout, Window Restoration, Woodwork Restoration [7].
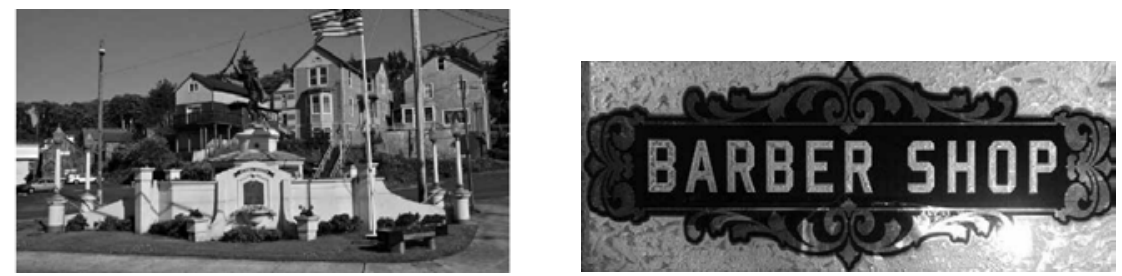

Picture 2. National Register Of Historic Places, 1984 [7]

Picture 3. Historic Glue Chipped Glass Sign [7].

Students work on historic Alderbrook Hall which is an early 20th Century PacificNorthwest Bungalow Style fire station. Other building is Doughboy Monument which is National Register of Historic Places [7].

Table 3. Architectural restoration program's courses (Example 3)

\begin{tabular}{|c|c|c|c|c|}
\hline \multicolumn{5}{|c|}{$\begin{array}{l}\text { Compulsory And Elective Courses } \\
\text { (Theoretical And Practical Education, AKTS) }\end{array}$} \\
\hline$\downarrow$ & (2) & (3) & (4) $\downarrow$ & (5) \\
\hline 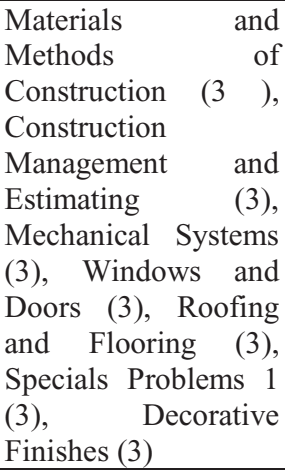 & $\begin{array}{l}\text { Architectural } \\
\text { Drafting and } \\
\text { Design (3), } \\
\text { Composition 1, }\end{array}$ & $\begin{array}{l}\text { Introduct } \\
\text { ion to } \\
\text { Historic } \\
\text { Preservat } \\
\text { ion (3), } \\
\text { Historic } \\
\text { Research } \\
\text { and } \\
\text { Docume } \\
\text { ntation } \\
(2)\end{array}$ & $\begin{array}{l}\text { History of } \\
\text { American } \\
\text { Architectur } \\
\mathrm{e} 1 \text { (3), } \\
\text { History of } \\
\text { American } \\
\text { Architectur } \\
\text { e 2(3) }\end{array}$ & $\begin{array}{l}\text { Field Lab Community } \\
\text { Service (1), Building } \\
\text { Pathology (4), Field Lab. } \\
\text { (1), Chemistry for } \\
\text { Conservation(3), Field Lab. } \\
\text { (1), Capstone (2) Directed } \\
\text { Studies } 1 \text { (3) Masonry and } \\
\text { Ceramics (3), Plaster and } \\
\text { Composition (3), Metals } \\
\text { (3), Stained Glass (3) }\end{array}$ \\
\hline
\end{tabular}

Table 4. Architectural restoration program's courses (Example 4) 


\begin{tabular}{|c|c|c|c|c|}
\hline \multicolumn{5}{|c|}{$\begin{array}{l}\text { Compulsory and Elective Courses } \\
\text { (Theoretical And Practical Education, AKTS) }\end{array}$} \\
\hline$\downarrow$ & $\downarrow$ & $\downarrow$ & 4 & $\downarrow$ \\
\hline $\begin{array}{l}\text { Project } \\
\text { Manageme } \\
\text { nt (3), } \\
\text { Residential } \\
\text { Materials } \\
\text { \& Methods } \\
\text { (3), } \\
\text { Printreadin } \\
\text { g for } \\
\text { Constructio } \\
\text { (3). }\end{array}$ & $\begin{array}{l}\text { Construction } \\
\text { Drawing (3), } \\
\text { Computer } \\
\text { Aided } \\
\text { Design } 1 \text { (4), } \\
\text { Computer } \\
\text { Graphics } 1 \\
\text { (4), } \\
\text { Computer } \\
\text { Aided } \\
\text { Design } 2 \text { (4), } \\
\text { Computer } \\
\text { Aided } \\
\text { Design 3 (4), } \\
\text { Computer } \\
\text { Graphics II } \\
\text { (3) }\end{array}$ & $\begin{array}{l}\text { Introduct } \\
\text { ion to } \\
\text { Historic } \\
\text { Preservat } \\
\text { ion } \\
\text { Historic } \\
\text { Preservat } \\
\text { ion } 1 \text { (3), } \\
\text { Historic } \\
\text { Preservat } \\
\text { ion } \\
\text { Project(4 } \\
\text { ) }\end{array}$ & $\begin{array}{l}\text { History } \\
\text { of } \\
\text { Pacific } \\
\text { Northwe } \\
\text { st (3) }\end{array}$ & $\begin{array}{l}\text { Dry Stack Masonry (3), Monument } \\
\text { Restoration (2), Fundamentals of } \\
\text { Woodworking (2), Faux Finish (1) } \\
\text { Techniques, Facade Restoration (2), } \\
\text { Wood Window Restoration (3), } \\
\text { Decorative Glass Glue Chipping(2), } \\
\text { Plaster Repair (2), Workshop: Dry Stack } \\
\text { Masonry, Blacksmithing, Building } \\
\text { Documentation, Column Restoration, } \\
\text { Deck Reconstruction, Documentation \& } \\
\text { Deconstruction, Door Analysis, Door } \\
\text { Reconstruction, Facade Restoration, Faux } \\
\text { Finish, Floor Framing, Historic Glass, } \\
\text { Millwork, Ornamental Plaster, Plaster, } \\
\text { Porch Restoration Roof Restoration, } \\
\text { Stained Glass, Stair Layout, Window } \\
\text { Restoration, Woodwork Restoration }\end{array}$ \\
\hline
\end{tabular}

\section{Conclusions}

It is undeniable that today's constructions are produced with an understanding that does not match the structural and spatial character of the traditional architecture of our country. At the same time, traditional building trades and crafts professions are disappearing. Technicians cannot be found in restoration construction. In this context, Architectural Restoration Associate Degree schools are important for the protection of our Cultural Heritages.

Since the graduates of this program work as technicians with the architects and the civil engineers, courses and internships given within this program are very important. In addition, learning to apply from local building masters will contribute to the maintenance of the disappearing professions. Traditional building craftsmen will be educated. At the same time, courses and the scope of the program are important because students who want to continue their academic career can pass to the Architecture or Interior Architecture (etc.) departments of their university.

Within the scope of the study, courses of the architectural restoration program have been researched. Courses required for the development of the "Architectural Restoration Associate Degree Program" have been examined. It is observed that curriculum includes "Drawing Courses, Building Constructions Courses, Conservation Technique Courses, History of Civilization-Art-Architecture Courses And Historical Heritages Courses" in the curriculum. Notwithstanding, in some universities, the internship lasts for one semester, while in some universities it is done as a summer internship. It is observed that the courses in "Preservation, Restoration, Technical Conservation and Methods" often take place in the curriculum in the Architectural Restoration Associate Degree Programs. However, it seems that the number of courses related to the "History of Architecture", "History of Art", and "History of Civilization" should be increased in the curriculums of the programs.

It is important to understand the value of Cultural Heritages in order to develop conservation methods. Students studying in the Architectural Restoration Programs of the universities will guide the future of the architecture. In order to protect the Cultural 
Heritage and to deliver it to the future generations, this education should be given to the students in a comprehensive way. Architectural Restoration Programs vary from different models and traditions. All programs are designed to have a similar infrastructure for the education of the students. However, one must not forget the difference of local cultures. For this reason, information on preservation of Cultural Heritage and knowledge on Architecture, Art and Civilization history is important in Architectural Restoration Associate education. In addition, with detailed drawing, theoretical and practical courses, workshops to be given in Architectural Restoration Programs, students will be successful "technical staff" in the historic buildings restorations or etc.

\section{References}

1. B. Uluengin, Rölöve. Yem Kitabevi, (2005).

2. D.E. Bilgiç, N. Konak, Tasarı Geometri, Teknik Resim Ve Perspektif Derslerinin Mimarlık Eğitimi Ve Düşünsel Altyapısına Etkisi Ve Prof. Dr. Yılmaz MORÇÖL, Mimarlık ve Yaşam Dergisi, Cilt:1 No:1, 2016(1-12).

3. D.Kuban, Tarihi Çevre Korumanın Mimarlık Boyutu. Yem Kitabevi, İstanbul, (2000)

4. M. Soygeniş, Yapı 2-3-4, Birsen yayınevi, İstanbul, (2000, 2002, 2003)

5. S. H. Eldem, Yapı 1, Birsen yayınevi, İstanbul, (2000)

6. URL. http://www.belmontcollege.edu/current-students/programs-of-study/buildingpreservationrestoration/

7. URL. https://www.clatsopcc.edu/preservation

8. URL. http://www.msgsu.edu.tr/tr-TR/mimari-restorasyon-programi/419/Page.aspx

9. URL . http://www.mst.yildiz.edu.tr/ 